\title{
インジウムを用いたガラス接着体中の応力
}

\author{
岸、井貫 \\ （東京芝浦電気株式会社）
}

\section{Stress in Glass-Indium-Glass Bi-metallic Composites}

\author{
By \\ Toru KISHII
}

(Tokyo Shibaura Electric Co., Kawasaki, Japan)

In electronic tube manufacturing industry, indium is used for cementing glass components to form vacuum-tight seals. Owing to its low melting point $\left(156^{\circ} \mathrm{C}\right)$ and yield strength, indium can cement together glasses with different thermal expansion coefficients or can form seals at relatively low temperature.

To examine effects of plasticity of indium on formation, distribution or release of stresses in seals, bi-metallic composites were formed from strips $\left(5 \times 10 \times 50 \mathrm{~mm}^{3}\right)$ of various kinds of glasses (silica glass, Kovar sealing and commercial plate glasses) by cementing with indium, and the stress was observed photo-elastically. Results were as follows: 1) Stress was nearly zero at ends and reached maximum at central parts of the composite, 2) Cooling rate after cementing did not so much affected stress in the composite, 3) By soaking at temperatures near melting point of indium, stress decreased in some degree, 4) During temperature cycles, stress showed hysteresis phenomena distinctly, 5) Observed stress near room temperature was far smaller than that calculated by assuming adhesion at melting point of indium and 6) Stress in glass caused by sticking of indium was hardly recognized.

The results were explained by putting several assumptions on plastic behaviour of indium layer, namely; 1) As yield strength of indium is low, stress near free surface of indium layer in the composite cannot be intense, 2) Bending moment in the composite or expansion difference between glass strips held per unit area of indium layer are restricted by yield strength of indium, 3) Increase of stress over this limitation is prevented by plastic flow of indium, 4) The limit decreases with increase of temperature and decreases quickly to zero near the melting point of indium and 5) By soaking at constant temperature the limit decreases. Degree of lowering is slight at room temperature and is distinct at relatively high temperature.

From the experimental results and the consideration described above, it is concluded that stress in the composite is mainly determined by shape or dimension of the composite including indium layer, as, well as by plastic properties of indium.

[Received June 16, 1965]

\section{I. 緒 言}

電子管工業に掓て，インジウムがガラスの接着に用 いられる。インジウムは低温度 $\left(156^{\circ} \mathrm{C}\right)$ で融け，ガラ スを濡らし，常温でも軟らかくて塑性変形しやすい，そ のため, 膨脹係数差の大きいガラスの封着, 耐熱的でな い回路素子をつけているガラスの接着に都合がよい，光 電導物質が形成されているビジコン前面ガラスの封着 は，インジウム利用の 1 例である.

インジウムを用いた接着体は，接着材の塑性のために 特殊な応力特性を示すと予想されたので，実験的に調べ ることを試みた。
図-1 のように, $3 \mathrm{~mm} \times 10 \mathrm{~mm} \times 50 \mathrm{~mm}$ のガラス片を インジウムで接着し, 光弹性で, 接着体内の応力分布, 接着体を加熱した時の応力の変化などを測った，使用し たガラスは，石英ガラス，コバール封着用ガラスおよび 市販板ガラスであった.常温附近での膨脹係数は $10^{-7} /{ }^{\circ} \mathrm{C}$ を単位として，それぞれ 7, 50，約 80 であった。

光弾性装置は水晶くさびを用いたもので, 視野内に黒 い干渉縞が現われ，試料の応力によって縞が変位する方 式のものであった。直接には, 縞の変位から光弾性的レ ターディション (単位 $\mathrm{m} \mu$ ) 功測定され, 以下に図示さ れた. ガラスの光弹性常数は， $(\mathrm{m} \mu / \mathrm{cm}) /\left(\mathrm{kg} / \mathrm{cm}^{2}\right)$ を单 位として, 石英ガラス 3.5 , コバール封着用ガラス 3.6 , 板ガラス 2.6 であり，これらを使ってレターデイショ 
ンから応力を算出でき

る.

接着体老加熱するに は電気炉を使った，測 定は常温に近い温度域 で行なわれたから，加 熱, 泠却の速さを自由 に調整することができ なかった、それゆえ，

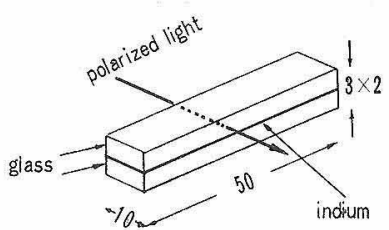

Fig. 1. Sample used for photoelastic stress measure. ment. (unit : mm)

温度変化の速さは比較的小さくし，ことにたとえば常温 附近での泠却は非常に遅かった.IV.7で述べるように， 温度变化速度が応力に及ぼす最終的な影響は大きくない

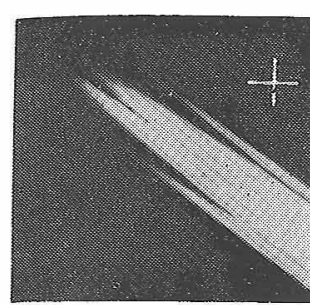

Fig. 2. Observation of a bi-metallic composite (silica glass-indiumplate glass) near its end between crossed nicols. Cross : directions of vibration of polarizer and analyzer の份度を変えてもほとんど変らず, 明るさが全体にわた り一様な割合で変わるだけであった，特に接着体を偏光 の振動方向と平行に置くと，全体がほぼ完全に暗くなっ

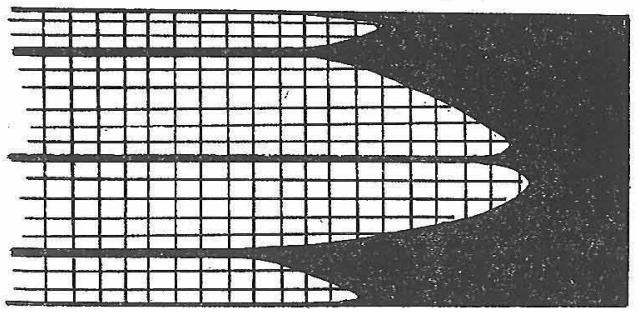

Fig. 3. Schematic representation of trajectories of principal stresses near end of bi-metallic composite Stress is hardly detected in black areas.

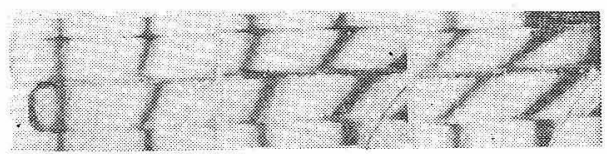

Fig. 4. Photoelastic observation of stress distribution in bi-metallic composite, by using quartz wedge. The direction from left to right in the photograph corresponds to the one from end to central part in the composite.
た.それゆえ，主応力線は，ガラス面と平行および直角 な方向へだけ伸びていると認められた（図-3）.

主忘力の方向分布は単純であるが，忘力の值は場所に より変化していた（図-4〜6)。すなわち，兩端部では 0 で，中央部が最大であった，接着後の冷却速度が府力に

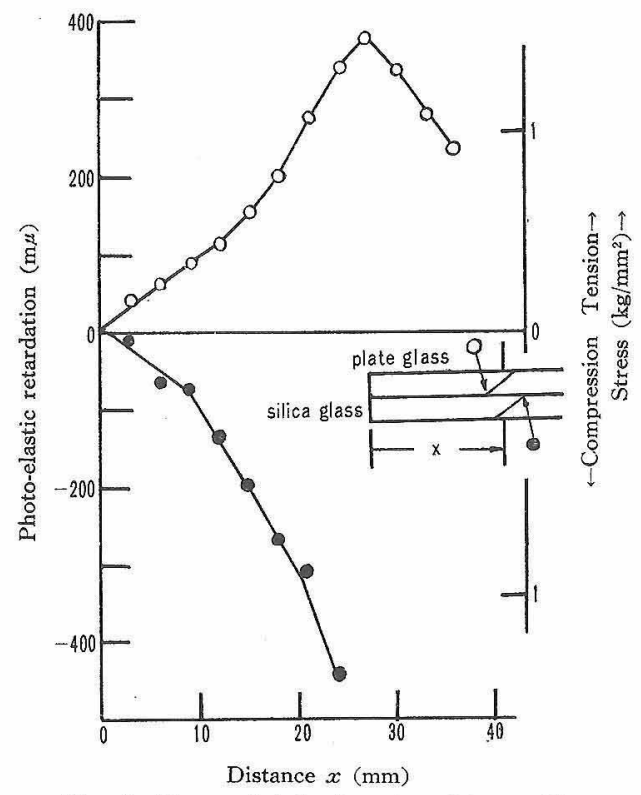

Fig. 5. Stress distribution in a bi-metallic silica glass-indium-plate glass composite

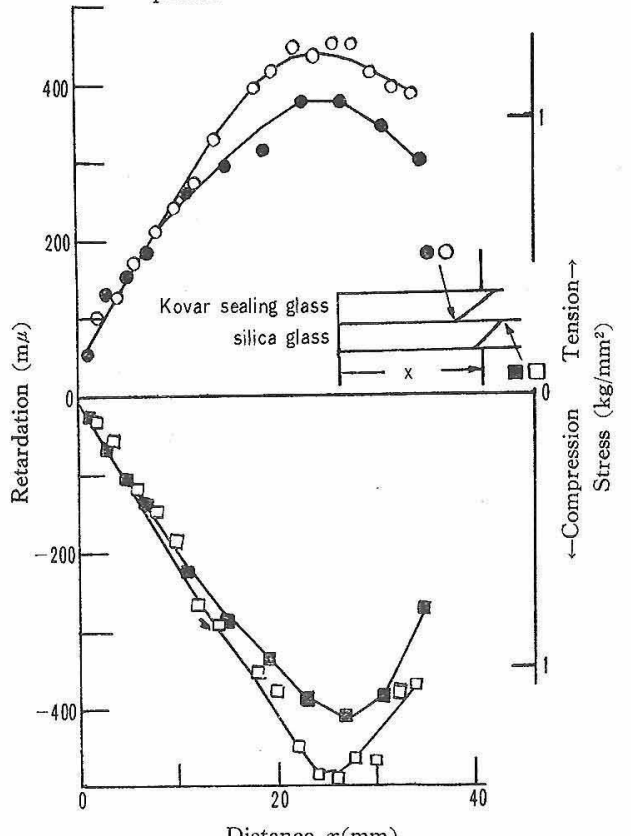

Fig. 6. Stress distribution in a bi-metallic silica glass-indium-Kovar sealing glass composite. Filled circles and tetragons : cooled in air after cementing. Open circles and tetragons : cooled slowly in electric furnace after cementing. 
及ぼす影響は，比較的小さかった（図一6).

\section{III.2 外部応力を加えた場合の応力分布の変化}

（石英ガラスーコバール封着用ガラス）接着体に曲证歪 みを加えると，応力分布が変化した（図-7). バイメタ ル作用による接着体の曲がりに対して，これを助長する ように曲げ歪みを加えた後の変化は小さかった，その逆 方向の曲げ歪みを加えると，变化が顕著で，應力の符号

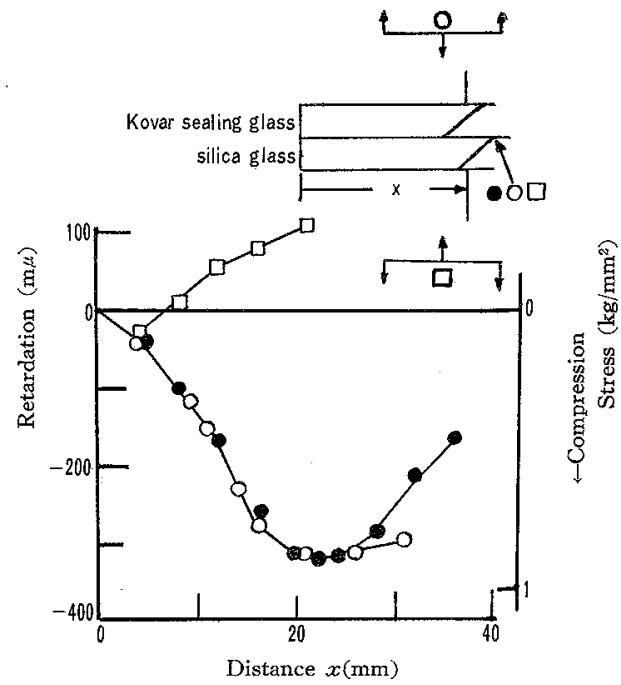

Fig. 7. Change of stress distribution in a composite by application of external bending stresses.

Filled circles : before applying bending stress. Open circles and tetragons : after application of bending stress.

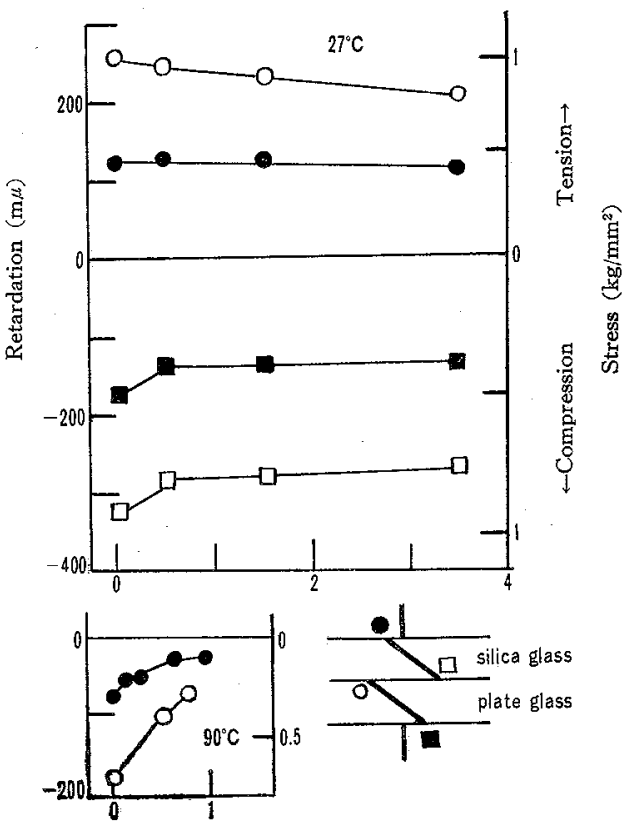

Time (hr)

Fig. 8. Change of stress during soaking at constant temperatures.
を逆転させることも可能であった。

\section{III.3 応力の時間的変化}

(石英ガラスー板ガラス) 接着体を， $27^{\circ} \mathrm{C}$ および $90^{\circ} \mathrm{C}$ に保持した時, 念力は. 図-8 のように変化した. $90^{\circ} \mathrm{C}$ では，応力が明らかに減少した。

\section{III.4 インジウムの付着による応力}

板ガラス片の面に，インジウムを厚さ約 $0.5 \mathrm{~mm}$ に盛 上げ，応力を測った．応力は認められたが，その值は非 常に小さく，また加熱しても増加しなかった（図-9）.

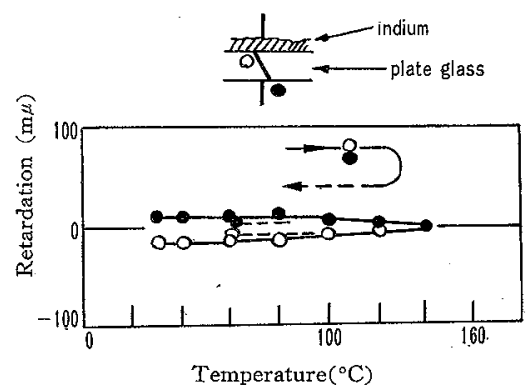

Fig 9. Stress in glass carrying thick layer of indium and its change with temperature.

III.5 温度变化にともなう応力の变化

（石英ガラスー板ガラス）接着体の中央部の応力は, 温 度変化にともない 図-10のように変った。これに対応 する光弾性写真を 図-11 に示した。

同じ接着体の，応力が中央部よりも小さい部分につい て，、ろいろの温度サイクルを与えて測ると，図-12の

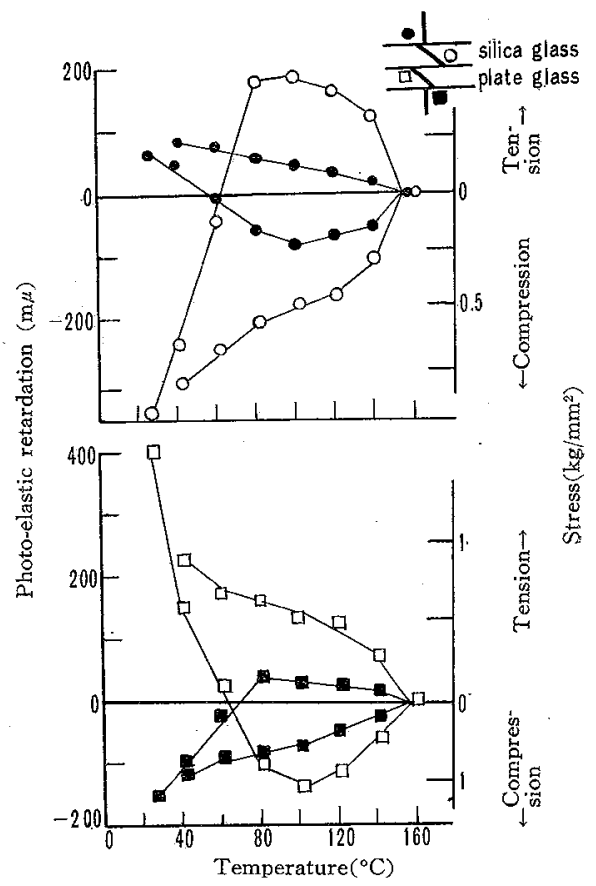

Fig. 10. Change of stress in a silica glassindium-plate glass composite with temperature. 
33 岸 并 貫

ようになった。

(石英ガラスーコバール封着用ガラス) 接着体で，その 中央部（図-13）と，端一寄った部分（図-14）の応力を 測った. 温度サイクルを与えた時の応力変化は, これら $2 つ の$ 場合定性的にはほぼ同じであった，応力の絶対值

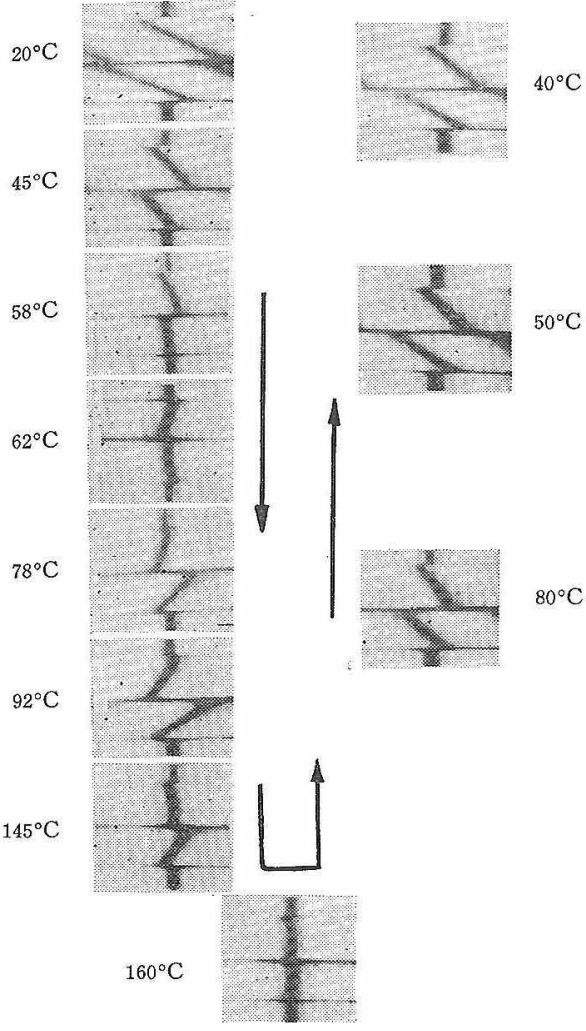

Fig. 11. Photo-elastic observation of stress in a silica glass-indum-plate glass composite during heating and successive cooling.

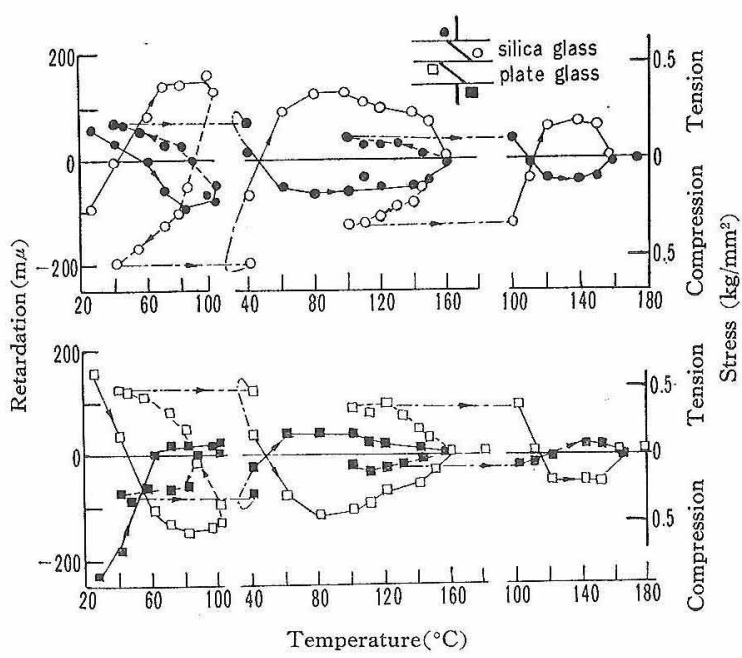

Fig 12. Change of stress in a silica glass-indiumplate glass composite during temperature cycles.

窸業協会颜 74[1] 196631

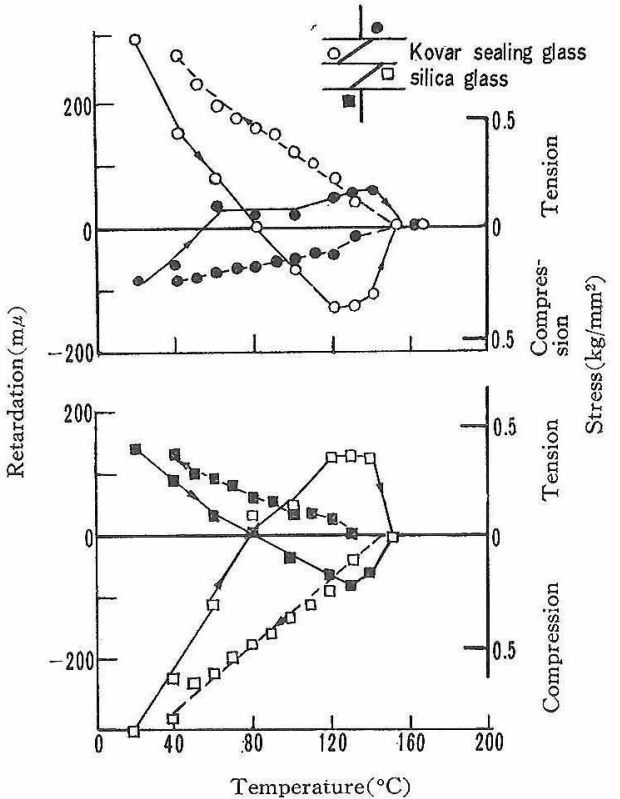

Fig. 13. Change of stress in a silica glass-indiumKovar sealing glass composite with temperature (I). At the central part.

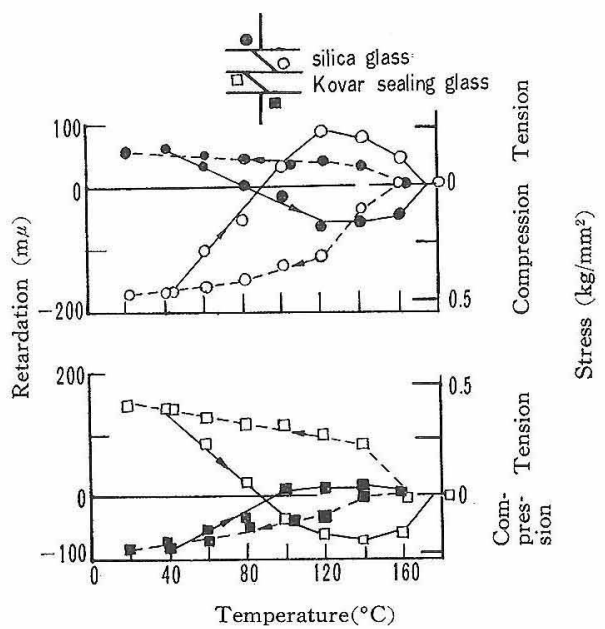

Fig. 14. Change of stress in a silica glass-indium-Kovar sealing glass composite with temperature (II). At the part with relatively low stress.

は，中央部の方が大きかった。

（板ガラスーコバール封着用ガラス）接着体に温度少イ クルを加えた場合の結果を図-15に示す。途中で定温 度保持をして，インジウムの塑性的匍匐の影響を調べた ものである．定温度保持の閒に応力は緩和するが，つぎ に温度変化を始めると応力が急激に変わり，定温度保持

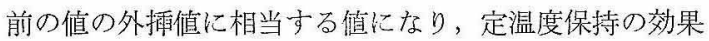
は見出されなくなってしまう。

IV. 考

IV.1 インジウムの塑性による応力緩和 


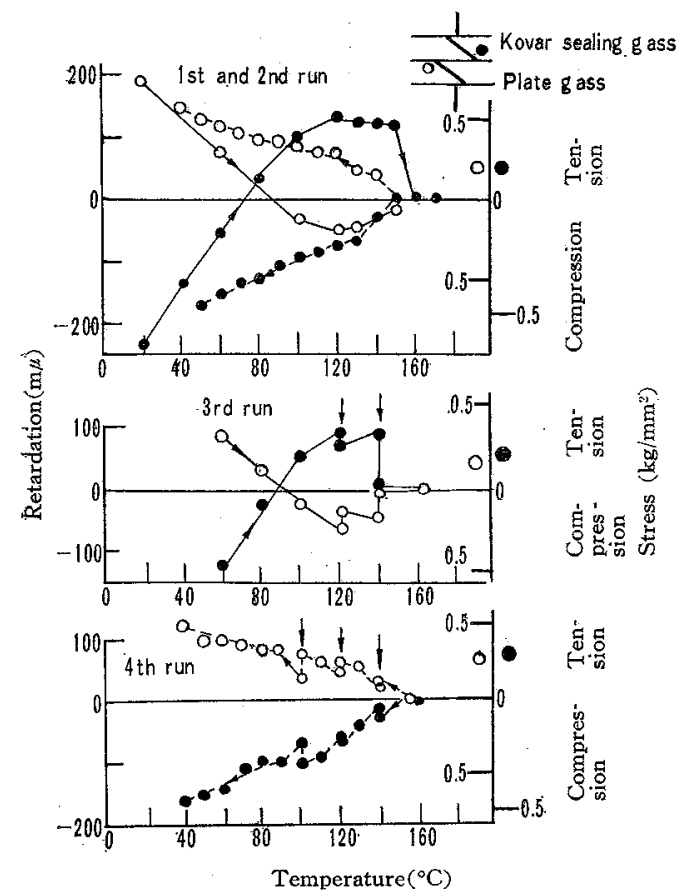

Fig. 15. Change of stress in a plate glass-indiumKovar sealing glass composite during temperature cycles $\downarrow$ : soaking at constant temperature for 30 minutes.

もしも膨脹係数の異なる 2 枚のガラス片が固く接着さ れ,弾性的にバイメタル作用で変形すると考える ${ }^{1223)}$. 両者のヤング率 $E$, 厚さ $a$ が等しいならば，接着面に 生ずる最大忘力は， $E \times \delta\left(\delta\right.$ は膨脹差) の $\left.1 / 2^{1}\right)$ ない し 4/72) 倍と予期される. $E$ は $700000 \mathrm{~kg} / \mathrm{cm}^{2}$ 程度で あり，膨脹係数 $\alpha$ の差 $4 \alpha$ は $4 \sim 8 \times 10^{-6} /{ }^{\circ} \mathrm{C}$ である. 從がってインジウムの融点と常温との間での $\delta$ は 6.5 $\sim 13 \times 10^{-4}$ で, 最大応力は $270 \sim 540 \mathrm{~kg} / \mathrm{cm}^{2}$ と算出さ れる. また温度変化 $1^{\circ} \mathrm{C}$ 当りの最大応力の変化量は, $2.8 \sim 5.6 \mathrm{~kg} / \mathrm{cm}^{2}$ である.

実測結果（図-5）では，応力は端部で 0 に近く，中央 部でも $150 \mathrm{~kg} / \mathrm{cm}^{2}$ を超えない.これは計算值よりかな り小さい，この差の原因はインジウム層が応力緩和に関 与するからであろう。

インジウム層が応力を緩和させる機構として, 次のよ うなものが考えられる：

(i) 2 枚のガラス片の間でのすべりを起させる.

(ii) インジウム層がガラス片とともに弾性変形を し, インジウム層がない場合に比べて, 発生する応力を 減らす.

(iii）インジウム層は,ガラスとの膨脹係数の差のた め, 温度変化がある時惊常に塑性流動をしている.この 流動忹, 恐らく接着体内の忘力学小さくする方向に作用 するであるう。
つぎに，温度変化にともなう応力変化の割合を調べ る.これは接着体の中央部について測り，かつ常温から 加熱していくか，または高温から冷却されたものが加熱 に転ずる場合の，狭い温度上昇の期間内のものだけは， 前記の計算值に近い（図-10，13）。しかしそれ以外の場 合にはすべて，計算值よりはるかに小さい，この原因 も, インジウム層の塑性的な挙動であるう.

\section{IV.2 インジウムの挙動}

III に㧍ける実験結果, または IV.1 の考察の結論な どを説明するために，インジウムが次のような塑性的な 挙動をすると仮定してみたい.

（1）インジウムの自由表面での忘力性, 実際上無視 できるくらい小さい，

（2）インジウム層が，その単位幅㐨よび単位長さ当 りに支えうる，ガラス間の膨脹差あるいはガラス内の曲 げ応力には限界がある。

（3）この限界以上の膨脹差や応力が生じようとする と，インジウムは塑性流動をしてガラス片閒にすべりを 起こさせ, 忘力の増加を防ぐ.

（4）この限界值は温度上昇とともに減少し，インジ ウムの融点近くで急減し，0に近づく。

（5）接着体を一定温度に長く保持することにより， この限界値を低下させうる. 低下の程度は, 常温では僅 かだが，インジウムの融点附近ではかなり著しい。

つぎに，インジウム層は有限の厚さを持つから，この 弾性変形も接着体の応力を小さくするのに役立つ. それ 故, 次のように仮定する.

（6）インジウム層が弾性変形をするならば，接着体 全体の変形や応力変化も弾性的である. 特にインジウム 層が十分薄ければ，接着体は近似的にはバイメタルの理 論に従った変形をする。

ただし，次の考察によって，インジウム層全体が弾性 的であるのは，かなり限られた温度変化域内だけである と推測される：

応力のない接着体があったと仮定する．これに温度変 化を与えると， 2 枚のガラス片間に膨脹差ができ, 応力 が発生する，むしすべての材料が弾性変形をするなら ば，大きい応力が端部に 集中する ${ }^{1)}$. それ故仮定 (2), （3）によって，この部分のインジウムが塑性変形を始め る.温度変化が大きくなるにつれて, 塑性変形を起して いる領域が中央部へ広がっていくと考えられる。このた めに, インジウム層を含めた接着体が厳密弾性的変形 をする温度範囲は，非常に狭いものと予想される．

以上の推定，仮定は一忘妥当なものと思われるが，厳 密には弾性論や塑性論によって裹付けされることが望ま しく,これは将来の問題としたい。これらによって, 実 験結果の検討と説明を試みる。

IV 3 インジゥムの自由表面の影響 
35 岸 井 貫

インジウムの塑性降伏強度を $P_{0}$ とし, 層内の 3 個の 主応力を $P_{1}, P_{2}, P_{3}$ とすれば，降伏の条件式は

$$
\left(P_{1}-P_{2}\right)^{2}+\left(P_{2}-P_{3}\right)^{2}+\left(P_{3}-P_{1}\right)^{2}=2 P_{0}^{2}
$$

となる.インジウムは軟らかいので， $P_{0}$ は小さい、イ ンジウム層のへりは自由表面になっており，表面に垂直 な応力は０である．従って降伏の条件式加ら，他の方向 の応力は $P_{0}$ を超えられず，インジウムがガラスに及ぼ し，またはガラス内に引き起す応力む小さい、バイメタ ル形接着体の端部で応力が小さいのは，このように説明 される・インジウムを盛り上げただけのガラスでは，イ ンジウムの表面が広くて，応力が大きくなりえないはず である(図-9).

\section{IV.4 インジウム層および接着体中の応力分布}

インジウム層は，その短辺だけでなく，長辺に沿って む自由表面がある. 従って, その層内に発生しうる応力 の最大值には，層の幅 (短辺の長さ), 愿さおむび $P$ から決まる限度がある。これは，層の長辺に沿う単位長 さ当りに支えらる，接着体の曲げ応力あるいはガラス間 の膨脹差に限度があることを意味し，仮定 (2) に対応 寸る，接着体中の态力は，この限界值を長さに沿って積 分したものに近く，しかも両端附近では０であるという 境界条件を置かれたものになる.その結果として，接着 体の応力分布は 罒-5,6のように，中央部に極大がある 形になると考えられる。

もしも接着体が長ければ，中央部の極大応力值も大き くなると予想される、しかしいくら長くても，インジウ ムなしでガラスが直接に接着された場合の值を超えるこ とはないであるう。

\section{IV.5 冷却時のインジウムの挙動}

インジウムを融解して，膨脹係数の異なるガラスを接 着した場合を考える. 泠却されてインジウムの融点 (図-16 M) に達すると，インジウムが固化し接着体に

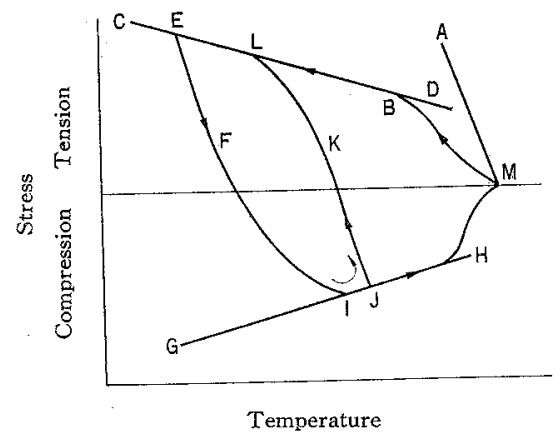

Fig. 16. Schematic explanation of temperaturestress characteristics of bi-metallic composite $\mathrm{M}$ : melting point of indium $\mathrm{MA}, \mathrm{EF}$ : change of stress following the theory of bi-metals, CD, GH: limits of stress determined by yield strength of indium, $\mathrm{F}, \mathrm{K}$ : the points where indium begins to flow.
窯業協会誌 74[1] $1966 \quad 33$

応力が発生する、インジウム層が薄く, か力弾性的に変 形するならば，态力はバイメタルの理論から計算される 值 (MA) に等しい，しかし実際には， $M$ 点附近では インジウムの塑性変形が顕著であり，匍匐もあって応力 の一部を緩和するので，态力はMAよりも小さく，MB に沿い変化する。

$\mathrm{CD}$ は，インジウムの塑性降伏強度から決まる応力の 值で, 恐らく低温度では高いと思われる. 応力が $\mathrm{C} D$ 線 に達すると, インジウムは塑性によって応力を緩和し， それ以上の応力発生を防ぐ. それ故, 応力は $\mathrm{CD}$ 線に沿 い変って行く.

\section{IV.6 加熱時の応力変化}

泠却されて $\mathrm{E}$ 点に相当する温度, 応力を示守接着体を， 加熱した場合を考える. 加熱すればガラス間に発生した 膨脹差は減じ, 応力は小さくなる、インジウム層中の応 力も降伏限界より低下寸るので, その挙動は弾性的であ る. 従って接着体は弾性的に变形し, 応力はMAに平行 な E F 線に沿い変わる。

しかしながら，弾性的に変形する場合，接着体の端部 にまず大きい応力が発生し，インジウムが塑性変形を始 める.この点が $\mathrm{F}$ 亿相当する. 塑性変形をする領域は順 次中央部まで広がり, 応力は $\mathrm{EF}$ F延長から離れる。応 力の絶対值任 0 を経て逆符号に変わる. その絶対值が大 きくなり， $\mathrm{CD}$ と屾逆符号の $\mathrm{GH}$ 線と $\mathrm{I}$ 点で交わる時 は, インジウム層は全体で塑性変形を起しており, 以後. の态力は I H に沿い変化する.さらに融点 $M$ に近づく と，インジウムの匍匐が顕著になり応力が下る， $\mathrm{M}$ 点で は応力は 0 になってしまう。これらの経過は, 図一10, 12〜15 によく表わされている.

\section{IV.7 温度サイクル下の応力の変化}

温度サイクルが与えられた時の接着体の応力変化は, 前記の場合にならっで考えればよい，たとえばJ点まで 加熱されてから冷却に移れば，JKL の経路をとるであ ろう。この経過は 図-12 などに示されている。

\section{IV.8 インジゥムの匍匐の効果}

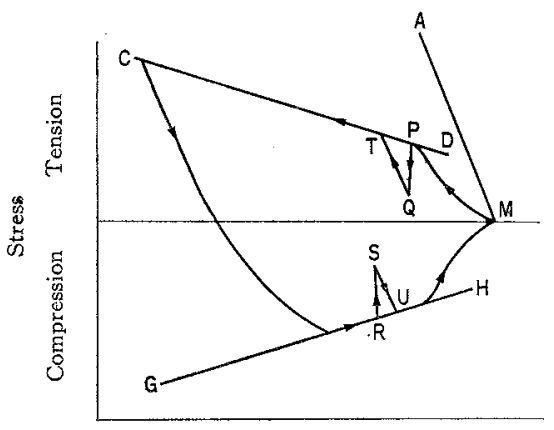

Temperature

Fig. 17. Schematic explanation of effects of soaking at constant temperatures and of creep of indium. 
インジウムの融点に近い温度に長く保持すると，応力 の絶対值はいくらか減少する（図-17 PQ,RS).つぎに 温度変化を与えると，インジウム層は匍匐のため応力が 小さくなっているから, 弾性的変形する. 応力忹 $\mathrm{Q}, \mathrm{S}$ などから MA に平行に変わるが，間もなく $\mathrm{CD}, \mathrm{GH}$ 線と交わり，それ以後の变化は前記の場合と同様にな る. 定温度保持は, 応力変化の有様に大き、影響を及ぼ さない。

\section{IV.9 応力に影響する他の要因}

今をでの説明からわかるように，接着体の応力に本質 的に影響するのはインジウム層の挙動であり，ついで層 の厚さを含めた接着体の形状である。それ蛇え、インジ ウムを用い北ば常に異種ガラスを接着できるとは限らな い. せた，インジウム層の厚さも，ある程度応力に影響 すると予想される。

\section{V. 総括}

膨脹係数の異なるガラス片をインジウムで接着したバ
イメタル形の試料の応力分布と, 温度変化にともなら応 力の変化とを, 光弾性で観察した. 接着体内の応力は端 部で 0 に近く，中央部で最大であった．虑力の大きさを 決める主要因は, ガラス間の膨脹係数差でなく, むしろ インジウム層の塑性降伏強度と，インジウム層の厚さを 含めた接着体の形とである．インジウムが塑性変形する ので, 温度変化にともなら応力の変化には顕著な履歴現 象があった，高温では，インジウムの塑性匍甸による応 力の緩和があるが，これは最終的な応力の值にはほとん ど影響しない，応力の履歴現象忹複雑であったが，イン ジウム層の挙動に関していくつかの仮定を設け, 統一的 に説明することができた。

\section{文献}

1) S. Timoshenko, J. Opt. Soc. Amer., 11; 233 (1925).

2) 不二門章，東芝レビェー，16，1577 (1961).

3) B.A. Boley, J.H. Weiner, "Theory of Thermal Stresses" p. 429

(6/16/1965 受付)

\section{岩石鉱物講習会テキスト}

B 5 判 タイプ騰写刷り 本文 68 ページ 実費 1000 円

既報の通り昭和 40 年 12 月 16 日から 3 日間にわたり東工大で開かれた講習会のテキストである. 先着 50 名に 貇り実費 1.000 円で扮頒けいたします.

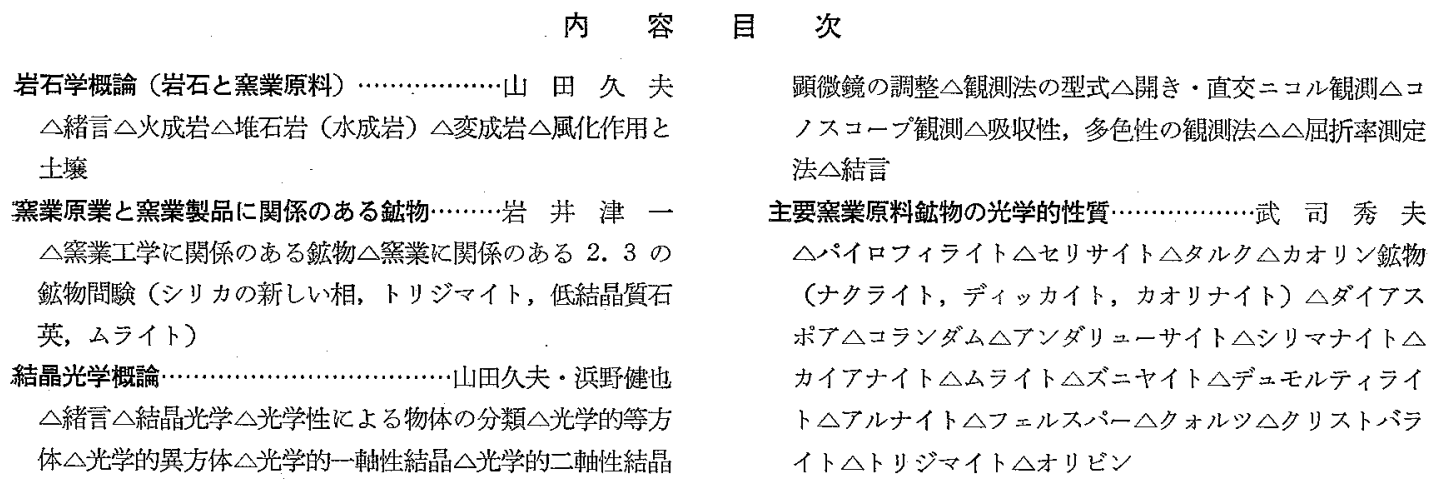

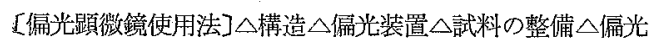

